\title{
Dominance of sphingomonads in a copper- exposed biofilm community for groundwater treatment
}

\section{Correspondence \\ J. González-López jgl@ugr.es}

Received 10 November 2006 Revised 5 November 2006 Accepted 9 November 2006
R. Vílchez, ${ }^{1} \dagger$ C. Pozo, ${ }^{1}$ M. A. Gómez, ${ }^{1,3}$ B. Rodelas ${ }^{1,2}$ and J. González-López ${ }^{1,2}$

\begin{abstract}
${ }^{1}$ Grupo de Microbiología Ambiental (Environmental Microbiology Research Group), Instituto del Agua, Escuela Superior de Ingenieros de Caminos, Canales y Puertos, Universidad de Granada, 18071 Granada, Spain

${ }^{2}$ Grupo de Microbiología Ambiental (Environmental Microbiology Research Group), Departamento de Microbiología, Facultad de Farmacia, Escuela Superior de Ingenieros de Caminos, Canales y Puertos, Universidad de Granada, 18071 Granada, Spain

${ }^{3}$ Grupo de Microbiología Ambiental (Environmental Microbiology Research Group), Departamento de Ingeniería Civil, Escuela Superior de Ingenieros de Caminos, Canales y Puertos, Universidad de Granada, 18071 Granada, Spain
\end{abstract}

The structure, biological activity and microbial biodiversity of a biofilm used for the removal of copper from groundwater were studied and compared with those of a biofilm grown under copper-free conditions. A laboratory-scale submerged fixed biofilter was fed with groundwater $\left(2.3 \mid \mathrm{h}^{-1}\right)$ artificially polluted with $\mathrm{Cu}(\mathrm{II})\left(15 \mathrm{mg} \mathrm{I}^{-1}\right)$ and amended with sucrose $\left(150 \mathrm{mg} \mathrm{l}^{-1}\right)$ as carbon source. Between 73 and $90 \%$ of the $\mathrm{Cu}$ (II) was removed from water during long-term operation (over 200 days). The biofilm was a complex ecosystem, consisting of eukaryotic and prokaryotic micro-organisms. Scanning electron microscopy revealed marked structural changes in the biofilm induced by $\mathrm{Cu}(\mathrm{II})$, compared to the biofilm grown in absence of the heavy metal. Analysis of cell-bound extracellular polymeric substances (EPS) demonstrated a significant modification of the composition of cell envelopes in response to $\mathrm{Cu}(\mathrm{II})$. Transmission electron microscopy and energy-dispersive X-ray microanalysis (EDX) showed that copper bioaccumulated in the EPS matrix by becoming bound to phosphates and/or silicates, whereas copper accumulated only intracytoplasmically in cells of eukaryotic microbes. $\mathrm{Cu}$ (II) also decreased sucrose consumption, ATP content and alkaline phosphatase activity of the biofilm. A detailed study of the bacterial community composition was conducted by $16 \mathrm{~S}$ rRNA-based temperature gradient gel electrophoresis (TGGE) profiling, which showed spatial and temporal stability of the species diversity of copper-exposed biofilms during biofilter operation. PCR reamplification and sequencing of 14 TGGE bands showed the prevalence of alphaproteobacteria, with most sequences (78\%) affiliated to the Sphingomonadaceae. The major cultivable colony type in plate counts of the copper-exposed biofilm was also identified as that of Sphingomonas sp. These data confirm a major role of these organisms in the composition of the $\mathrm{Cu}(\mathrm{II})$-removing community.
†Present address: Helmholtz Center for Infection Research, Department of Cell Biology and Immunology, Inhoffenstraße 7, D38124 Braunschweig, Germany.

Abbreviations: DGGE, denaturing gradient gel electrophoresis; EDX, energy-dispersive X-ray microanalysis; EPS, extracellular polymeric substances; LOI, loss on ignition; SEM, scanning electron microscopy; TEM, transmission electron microscopy; TGGE, temperature gradient gel electrophoresis; UPGMA, unweighted pair grouping with arithmetic averages.

\section{INTRODUCTION}

Copper is an essential trace element for all species studied to date, including humans (Fraga, 2005). However, a large excess intake of $\mathrm{Cu}(\mathrm{II})$ in drinking water can cause nausea, gastric irritation and vomiting, while long-term copper intoxication generates liver disease and severe neurological defects in humans (Hotz et al., 2003; Uriu-Adams \& Keen, 2005). Chronic ingestion of drinking water with high $\mathrm{Cu}(\mathrm{II})$ concentrations (over $3 \mathrm{mg} \mathrm{l}^{-1}$ ) is thus a potential health risk, especially for susceptible populations like children (Critchley et al., 2004; Uriu-Adams \& Keen, 2005). Cu(II) 
input in freshwaters is generated from a number of anthropogenic activities (Cameron, 1992), where these ions sequentially accumulate in sediments, bacteria, tubicid worms and fish, followed by uptake by humans through the trophic chain (Mulligan et al., 2001; Tchounwou et al., 1996). Copper is included on the US Environmental Agency (EPA) list of priority pollutants (Cameron, 1992), and its discharge in water is regulated in the European Union by the 76/464/EEC and 80/68/EEC Directives.

In recent years, the removal of toxic metal ions by biological methods based on the use of microbial biomass has been suggested as an attractive, low-cost alternative to the conventional physico-chemical processes, with important applications in remediation strategies (von Canstein et al., 1999; Costley \& Wallis, 2001; Eccles, 1999; Malik, 2004; Mulligan et al., 2001). Micro-organisms have coexisted with heavy metals in contaminated ecosystems since early times, and the selective pressure of heavy metal pollution triggered the evolution of metal-specific tolerance mechanisms (Bruins et al., 2000). Mechanisms of microbial tolerance to heavy metal ions include enzymic transformation, precipitation and bioaccumulation (Bruins et al., 2000; Malik, 2004; Valls \& De Lorenzo, 2002). The nature of the bioaccumulation depends on both the particular metal and the micro-organism. Copper ions are toxic due to their uncontrolled redox activity, responsible for the intracellular generation of superoxide and other reactive oxygen species, which damage biological macromolecules and induce cell death (Rensing \& Grass, 2003; Rutheford \& Bird, 2004). Moreover, when $\mathrm{Cu}(\mathrm{II})$ enters the bacterial cells it is reduced to the more toxic form $\mathrm{Cu}(\mathrm{I})$ (Rensing \& Grass, 2003). The intracellular copper is thus exclusively $\mathrm{Cu}(\mathrm{I})$, which does not occur in free form, as it rapidly reacts by binding to thiol groups and certain amino acid residues such as cysteine, leading to oxidation and cross-linking between proteins, which results in their impaired activity (Silver \& Phung, 2005; Tchounwou et al., 1996). Bacterial resistance to copper toxicity has been studied in detail in only a few bacterial species (Pseudomonas syringae, Xanthomonas campestris, Escherichia coli, Enterococcus hirae). The mechanisms, not yet fully understood, include the periplasmic retention of copper ions and the extrusion of copper from the cytoplasm and periplasmic space, which depends on several enzymes that protect the cell from copper damage (Rensing \& Grass, 2003; Rosen, 2002; Silver, 1996; Silver \& Phung, 2005).

In this study, a laboratory-scale submerged biofilter with a fixed biofilm was set up for the removal of $\mathrm{Cu}$ (II) from polluted groundwater, in order to characterize changes in the biofilm community exposed to copper, and to get an insight into the mechanisms of retention of the heavy metal ion. We compared the structure, mean extracellular polymeric substance (EPS) composition, biological activities and biological diversity of the biofilms formed in either the absence or presence of groundwater amended with $15 \mathrm{mg} \mathrm{Cu}(\mathrm{II}) \mathrm{l}^{-1}$. Biological structures involved in copper accumulation were detected by energy-dispersive X-ray microanalysis (EDX). Major cultivable populations in the copper-contaminated biofilm were isolated and bacterial strains were characterized by sequencing of the $16 \mathrm{~S}$ rRNA gene. Community profiles of biofilm bacteria were also studied by a culture-independent approach, based on temperature gradient gel electrophoresis (TGGE) and phylogenetic analysis of separated TGGE bands that were reamplified and sequenced.

\section{METHODS}

Description of the laboratory-scale biofilter. The laboratoryscale biofilter used for the experiments consisted of a methacrylate cylindrical column ( $0.5 \mathrm{~m}$ high, $0.15 \mathrm{~m}$ inner diameter), packed with clayey schists as carrier material for the formation of the biofilm. The characteristics of the carrier material are described in detail elsewhere (Gómez et al., 2002). Absence of $\mathrm{Cu}$ (II) ions in the carrier material was previously checked, as well as the content of phosphate $\left[0.1-0.5 \mu \mathrm{g} \mathrm{PO}_{4}^{3-}(\mathrm{g} \text { carrier material })^{-1}\right]$. The presence of magnesium, aluminium, calcium and iron in the carrier was detected by EDX.

The biofilter had five sampling ports (numbered p-0 to p-4), at $10 \mathrm{~cm}$ intervals along the length of the column. The system was fed with artesian groundwater, collected weekly from a well in Churriana (Granada, Spain) and introduced into a $0.2 \mathrm{~m}^{3}$ tank, from which it entered the biofilter. The mean characteristics of the groundwater used in the study were analysed during one year at four different times $(n=8)$, in accordance with the Standard Methods for the Examination of Water and Wastewater (APHA, 2001) and were the following: $\mathrm{COD}, 180 \pm 10 \mathrm{mg} \mathrm{l}^{-1}$; $\mathrm{BOD}_{5}, 145.2 \pm 0.8 \mathrm{mg} \mathrm{l}^{-1}$; mesophiles at $20{ }^{\circ} \mathrm{C}(48 \mathrm{~h}), 104 \pm 25$ c.f.u. $\mathrm{ml}^{-1}$; enterococci, not detected; E. coli, not detected; phosphates, $0.40 \pm 0.05 \mathrm{mg} \mathrm{l}^{-1} ; \mathrm{SO}_{4}^{2-}$, $178.90 \pm 0.07 \mathrm{mg} \mathrm{l}^{-1} ; \quad \mathrm{Cl}^{-}, \quad 50.70 \pm 0.08 \mathrm{mg} \mathrm{l}^{-1} ; \quad \mathrm{Na}^{+}, \quad 250.0 \pm$ $0.6 \mathrm{mg} \mathrm{l}^{-1} ; \mathrm{K}^{+}, \quad 7.50 \pm 0.05 \mathrm{mg} \mathrm{l}^{-1} ; \quad \mathrm{NO}_{3}^{-}, \quad 121.3 \pm 0.8 \mathrm{mg} \mathrm{l}^{-1}$; $\mathrm{NO}_{2}^{-}$, not detected; $\mathrm{NH}_{4}^{+}, 2.2 \pm 0.5 \mathrm{mg} \mathrm{l}^{-1}$; heavy metals $(\mathrm{Cu}, \mathrm{Cd}$, $\mathrm{Hg}, \mathrm{Cr}, \mathrm{Pb})<0.0001 \mathrm{mg} \mathrm{l}^{-1}$. When copper removal was studied, $\mathrm{CuSO}_{4} \cdot 5 \mathrm{H}_{2} \mathrm{O}$ was added to the influent water to get a final concentration of $15 \mathrm{mg} \mathrm{Cu}(\mathrm{II}) \mathrm{l}^{-1}$.

Biofilter inoculation. Because of the low microbial population present in the groundwater to be treated, prior production of a biofilm was needed (Gómez et al., 2002). This was achieved by inoculation of the biofilter with an activated sludge collected from an urban wastewater treatment plant (EDAR Los Vados, Granada, Spain). The sludge $(15 \mathrm{l})$ was amended with sucrose $\left(10 \mathrm{~g} \mathrm{l}^{-1}\right)$ and recirculated for $24 \mathrm{~h}$ at a flow rate of $100 \mathrm{ml} \mathrm{min}{ }^{-1}$. Then the groundwater to be treated was pumped into the biofilter together with sucrose as carbon source. The amount of sucrose added to the influent water was optimized in preliminary tests to $150 \mathrm{mg} \mathrm{l}^{-1}$, on the basis of using a concentration that guaranteed the feeding of the microorganisms throughout the whole filter depth, minimizing the concentration of sucrose present in the effluent water.

Parameters of operation. The influent water flow was kept at $2.31 \mathrm{~h}^{-1}$, regulated by a peristaltic Watson Marlow 505S pump. The column was supplied with an airflow of $11 \mathrm{~min}^{-1}$, controlled by a Dynaval Air rotameter. The flow of air was sterilized using a membrane filter of $0.2 \mu \mathrm{m}$ (Millipore), which was changed every 2 weeks.

In order to avoid filter clogging, and to optimize $\mathrm{Cu}$ (II) elimination from inflow water, cleaning cycles of the biofilters were carried out every 10 days by backflushing from the column base. The packing was loosened, firstly by a constant flow of air $\left(80 \mathrm{~m}^{3} \mathrm{~m}^{-2} \mathrm{~h}^{-1}\right)$ for $30 \mathrm{~s}$, and secondly by a constant increased flow of water $\left(15 \mathrm{~m}^{3} \mathrm{~m}^{-2} \mathrm{~h}^{-1}\right)$ 
and air $\left(60 \mathrm{~m}^{3} \mathrm{~m}^{-2} \mathrm{~h}^{-1}\right)$ for $30 \mathrm{~s}$. Finally, a steadily high flow of water $\left(15 \mathrm{~m}^{3} \mathrm{~m}^{-2} \mathrm{~h}^{-1}\right)$ without air was applied for $30 \mathrm{~s}$ to eliminate the remaining excess biofilm. The biofilter operated for 21 complete cycles of 10 days ( 7 months) for each separate biofilter (control groundwater or $\mathrm{Cu}(\mathrm{II})$-amended water).

Monitoring of sucrose concentration. Sucrose concentration in influent water, effluent water and sampling ports p-1 to p-4 was measured by the method of Roe \& Papadopoulos (1954), based on the detection of ketoses through the Seliwanoff reaction by heating $\left(80^{\circ} \mathrm{C}\right)$ with $5 \mathrm{M}$ hydrochloric acid. Pure sucrose was used for the construction of standard curves. Measurements were done at the beginning and end of each cycle of operation of the biofilter (days 1 and 9).

Monitoring of $\mathbf{C u}$ (II) concentration. $\mathrm{Cu}$ (II) concentration was monitored daily in both the influent and effluent water by atomic absorption using electrothermal atomization in a graphite furnace (Perkin-Elmer 4100-ZL).

Sampling of carrier with adhered biofilm. Pieces of the carrier material with biofilm were taken from the column through the four sampling ports available for this purpose. The pieces taken were replaced with sterile packing material, and the quantities removed at each particular sampling time did not significantly disturb the biofilter.

Organic matter content (quantification of organic matter). Organic matter was estimated by loss on ignition (LOI) of biofilm samples, based on sequential heating of samples to calculate the weight of organic matter (Dean, 1974). Wet pieces (20 g) of carrier material with adhering biofilm were placed in empty pre-weighed porcelain crucibles. After oven-drying of the samples to constant weight $\left(24 \mathrm{~h}\right.$ at $\left.120^{\circ} \mathrm{C}\right)$, organic matter was combusted at $550{ }^{\circ} \mathrm{C}$ in a Selecta muffle furnace with digital temperature display and thermostatic temperature control. Then LOI was calculated from the subtraction of weights before and after combustion. All samples were cooled to room temperature in a desiccator before any weight determinations. Organic matter content of the biofilm is reported as $\mathrm{mg}$ volatile compounds per $\mathrm{g}$ dry weight of carrier material.

ATP extraction and determination of ATP content. Fifteen grams of carrier material with adhering biofilm was suspended in $5 \mathrm{ml}$ DMSO buffered at $\mathrm{pH} 7.8$ (Tris/ $\mathrm{HCl}, 0.5 \mathrm{M}$ ), sonicated for $15 \mathrm{~min}$ and then vortexed for $5 \mathrm{~min}$. The suspension was collected, its volume measured, and then centrifuged at $1500 \mathrm{~g}$ for $10 \mathrm{~min}$. The method described by Karl (1980), based on firefly bioluminescence, was used for the quantification of ATP in samples of $50 \mu \mathrm{l}$ supernatant, using the Sigma ATP Bioluminescence Assay Kit and a bioluminescence photometer (Turner Designs). Results are given as ng ATP per mg organic matter.

Scanning electron microscopy (SEM), transmission electron microscopy (TEM) and electron-dispersive $X$-ray microanalysis (EDX). Individual pieces of carrier material with biofilm were removed from the column and fixed with $2.5 \%$ glutaraldehyde at $\mathrm{pH} 7.4$ (sodium cacodylate buffer, $0.05 \mathrm{M})$ at $4{ }^{\circ} \mathrm{C}(24 \mathrm{~h}$ for SEM, $4 \mathrm{~h}$ for TEM), washed, and post-fixed in $\mathrm{OsO}_{4}$ before being dehydrated in an ethanol gradient. Samples for SEM were critical-point dried using liquid $\mathrm{CO}_{2}$ in a Polaron CPD7501 apparatus. Samples for TEM were embedded in Epon resin and polymerized. Ultrathin sections $(70 \mathrm{~nm})$ were prepared with an Ultracut E ultramicrotome and stained with uranyl acetate and lead. Carbon coating was done in a Hitachi evaporator.

Samples were observed and analysed with a DSM 950 Zeiss SEM coupled to an Oxford ISIS 300 EDX system, or a TEM/STEM Philips CM20 coupled to an EDAX EDX system. Images were taken with a SIS MegaView III camera.
Recovery of cell-bound EPS from the biofilm and analysis of its composition. The following method was developed to recover cell-bound EPS from the biofilms, by modification of previously described physical methods (Nielsen \& Jahn, 2002). Wash water produced during the cleaning cycle of the biofilter, which contained abundant biofilm material, was used as substrate for EPS recovery.

A volume of 251 of wash water was decanted using Inhoff cones and the supernatant was removed until the volume was reduced to 21 . The concentrated biofilm suspension was sonicated at room temperature (Ultrasonic bath, Selecta) for $2 \mathrm{~min}$ at $40 \mathrm{kHz}\left(0.05 \mathrm{~W} \mathrm{ml}^{-1}\right)$ to homogenize the biofilm, and then centrifuged at $30000 \mathrm{~g}$ in a Beckman Avanti J centrifuge for $1.5 \mathrm{~h}$. The resulting pellet was resuspended in 21 distilled water, and the process repeated. The resulting supernatants did not contain EPS and were discarded.

The washed biofilm pellet was resuspended in 11 distilled water and heated for $2 \mathrm{~h}$ in a water bath at $80^{\circ} \mathrm{C}$, before being sonicated for $15 \mathrm{~min}$ at $40 \mathrm{kHz}\left(0.05 \mathrm{~W} \mathrm{ml}^{-1}\right)$ and placed in an orbital shaker at 200 r.p.m. for 24 h. This suspension was centrifuged again at $30000 \mathrm{~g}$ for $1.5 \mathrm{~h}$. The supernatant was collected, after which the pellet was resuspended in 11 distilled water, and the process repeated. The two supernatants were pooled, 3 vols chilled ethanol $\left(96 \% \mathrm{v} / \mathrm{v},-80^{\circ} \mathrm{C}\right)$ was added, and the EPS allowed to precipitate at $4{ }^{\circ} \mathrm{C}$ overnight. EPS flocs were collected and dried under an argon flow. Dry EPS was resuspended in distilled water, dialysed for $24 \mathrm{~h}$ against distilled water with several water changes, and freeze-dried.

Quantification of organic matter in the recovered EPS was determined by LOI as described above, and reported as g per $100 \mathrm{~g}$ dry weight of EPS. Content of total carbohydrates, proteins, uronic acids and acetyl groups was quantified by previously described methods (Blumenkrantz \& Asboe-Hansen, 1973; Bradford, 1976; Dubois et al., 1956; McComb \& McCready, 1957). In order to avoid interferences due to the presence of heavy metals in the samples, 0.1 M EDTA was added to samples and standards when appropriate.

Biofilm recovery from the carrier material. Biofilm samples were removed from the carrier material by the following method. A sample (10-100 g) carrier material with adhering biofilm was taken from each sampling port as described previously and placed in flasks with $50 \mathrm{ml}$ sterile saline $(0.9 \% \mathrm{NaCl} \mathrm{w} / \mathrm{v})$. In order to detach the biofilm from the carrier and disperse the cells, the suspensions were sonicated for $1 \mathrm{~min}$ and then placed in an orbital shaker at 155 r.p.m. for $1 \mathrm{~h}$. The process was repeated twice. The suspensions of biofilm material were then used for plate counts, isolation of cultivable bacteria, quantification of alkaline phosphatase activity and DNA extraction.

Determination of cultivable cell numbers, isolation and identification of colony isolates from the biofilm. Biofilm suspensions were serially diluted in sterile isotonic saline and plated on TSA medium (Triptic Soy Agar, Difco). Plates were incubated at $30{ }^{\circ} \mathrm{C}$ for $48 \mathrm{~h}$. Colonies isolated from $\mathrm{Cu}(\mathrm{II})$-removing biofilms were further purified by restreaking on TSA. Single colonies were used directly for the amplification of the nearly full-length $16 \mathrm{~S}$ rRNA gene, as previously described (Pozo et al., 2002). Identification was done by database comparison of the partial 16S rRNA gene sequences.

Alkaline phosphatase activity. Total alkaline phosphatase activity was measured in biofilm suspensions by a modification of the method previously described by Berman (1970). One millilitre of biofilm suspension was added to a mixture of $2 \mathrm{ml}$ of carbonate/ bicarbonate buffer $(0.2 \mathrm{M}, \mathrm{pH} 9.6)$ and $1 \mathrm{ml}$ of a p-nitrophenyl phosphate solution $(1 \% \mathrm{w} / \mathrm{v})$. After $30 \mathrm{~min}$ incubation at $37^{\circ} \mathrm{C}$ in the dark, the reactions were stopped by addition of $2 \mathrm{ml} \mathrm{NaOH}$ 
$(0.2 \mathrm{M})$. Samples were centrifuged at $1500 \mathrm{~g}$ for $10 \mathrm{~min}$ and absorbance at $410 \mathrm{~nm}$ was measured in a Hitachi U2000 spectrophotometer. Results were given as mg p-nitrophenol released (mg organic matter $)^{-1} \mathrm{~h}^{-1}$.

DNA extraction from biofilms. Total DNA was periodically extracted following a method based on that of Watanabe et al. (1998). A volume of $100 \mathrm{ml}$ sterile isotonic saline with suspended biofilm recovered from the carrier material was centrifuged at $1500 \mathrm{~g}$ for $30 \mathrm{~min}$, and the pellets were suspended in $1 \mathrm{ml}$ buffer $[10 \mathrm{mM}$ Tris/HCl $(\mathrm{pH} 8.0), 100 \mathrm{mM}$ EDTA, $0.35 \mathrm{M}$ sucrose and $20 \mathrm{mg}$ lysozyme $\mathrm{ml}^{-1}$ ] and incubated at $37^{\circ} \mathrm{C}$ for $10 \mathrm{~min}$. After incubation, $1.5 \mathrm{ml}$ lysis buffer $[100 \mathrm{mM}$ Tris/ $\mathrm{HCl}(\mathrm{pH} 8.0), 0.3 \mathrm{M}$ $\mathrm{NaCl}, 100 \mathrm{mM}$ EDTA, $2 \%(\mathrm{w} / \mathrm{v})$ SDS, $200 \mu \mathrm{g}$ proteinase $\mathrm{K} \mathrm{ml}^{-1}$ and $2 \%(\mathrm{w} / \mathrm{v}) 2$-mercaptoethanol] was added and samples were incubated at $37^{\circ} \mathrm{C}$ for $1 \mathrm{~h}$. Lysates were extracted twice with $1 \mathrm{vol}$. of phenol/chloroform solution $(1 / 1, \mathrm{v} / \mathrm{v})$, incubated for $10 \mathrm{~min}$ with $125 \mu \mathrm{g}$ RNase (ml sample) ${ }^{-1}$ and extracted once with 1 vol. chloroform. Aliquots of $800 \mu \mathrm{l}$ were precipitated with 1 vol. 2-propanol (30 min incubation at $-20^{\circ} \mathrm{C}$ followed by centrifugation for $20 \mathrm{~min}$ at full speed in a table-top centrifuge). The pellets were washed with $500 \mu \mathrm{l}$ of a $70 \%(\mathrm{v} / \mathrm{v})$ ethanol solution before being resuspended in $50 \mu \mathrm{TE}$ buffer and left to rehydrate at $4{ }^{\circ} \mathrm{C}$ overnight.

PCR. The 16S rRNA gene was used as target for the study of bacterial diversity by TGGE. Fragments of the gene of a size adequate for TGGE separation ( $200 \mathrm{bp}$ ) were amplified by PCR, using a nested approach, as this strategy has been previously reported to avoid non-specific priming, improve amplification of species present in low numbers, and yield richer band patterns in denaturing gradient gel electrophoresis (DGGE) (Nicolaisen \& Ramsing, 2002; Ward \& O'Mullan, 2002). The V3-hypervariable region of the 16S rRNA gene was selected because of its high inter-species variability and the reliability of previously described universal eubacterial primers for DGGE studies (Yu \& Morrison, 2004). Primers fD1 and rD1 (Weisburgh et al., 1991) were used to amplify a $1.5 \mathrm{~kb}$ fragment of the 16S rRNA gene, then primers P1-GC and P2 (Muyzer et al., 1993) were used in a nested PCR to amplify the V3 region. All primers used were purchased from Sigma-Genosys and purified by HPLC.

A volume of $1 \mu \mathrm{l}(2-5 \mathrm{ng})$ DNA was used as template for PCR, and subsequently $1 \mu \mathrm{l}$ of the first PCR product was used as template for the nested PCR. Ampli Taq Gold polymerase (Applied Biosystems) was used in all experiments. Conditions for the PCR reactions were kept as previously described for both amplifications (Vinuesa et al., 1998; Watanabe et al., 1998), except for the extension of the first denaturation step to $7 \mathrm{~min}$, as required by Ampli Taq Gold polymerase. Final PCR products were cleaned using Microcon YM cartridges. Final concentration of DNA samples was 60-100 ng $\mu \mathrm{l}^{-1}$. From 2 to $5 \mu \mathrm{l}$ was loaded in each well for TGGE.

TGGE and DNA sequencing. TGGE runs were done on a TGGE Maxi system (Whatman-Biometra). Denaturing gels (6\% PAGE with $20 \%$ deionized formamide, $2 \%$ glycerol and $8 \mathrm{M}$ urea) were made and run with $2 \times$ TAE buffer. The temperature gradient applied for efficient separation of bands was optimized at $43-63^{\circ} \mathrm{C}$. The gels were electrophoresed at $125 \mathrm{~V}$ for $18 \mathrm{~h}$. Gel bands were visualized by silver staining using the Gel Code Silver Staining kit (Pierce), following the manufacturer's recommendations, except for the omission of the stabilization step. Stained gels were photographed with a Canon digital camera.

Portions of individual bands on silver-stained TGGE gels were removed with sterile pipette tips, placed in $10 \mu$ f filtered and autoclaved water, and directly used for reamplification with the appropriate primers. PCR products were purified by running in gels and extraction with the Quiaex-II kit (Qiagen). Reamplified and purified DNA fragments, which were rerun on TGGE, migrated to the same location as the original bands in the mixed template profiles. The DNA was directly used for automated sequencing in an ABI PRISM 3100 Avant Genetic Analyser.

Image analysis, biocomputing and phylogenetic analysis. Band patterns generated by TGGE were compared and clustered using the Quantity One image analysis software, version 4.6.1 (BioRad). Bands were automatically detected and matched, and further corrections were applied manually. The selected clustering method was unweighted pair grouping with arithmetic averages (UPGMA).

DNA sequences were analysed using the biocomputing tools provided on-line by the European Bioinformatics Institute (http://www.ebi. ac.uk). The BLASTN (Altschul et al., 1997) program was used for preliminary sequence similarity analysis. The CLUSTALX version 1.8 software (Jeanmougin et al., 1998) was used for the aligning of sequences. Phylogenetic and molecular evolutionary analyses were conducted using MEGA version 2.1 (Kumar et al., 2001). Gaps were excluded from the analysis. Bootstrap values below $50 \%$ are not shown in the tree.

Statistics. The effects of the presence of copper, and the depth of sampling in the biofilter column, on the parameters studied were evaluated by either one-way or multifactor analysis of variance (ANOVA), using the software package STATGRAPHICS 5.0 (STSC Inc.) to identify significant differences between measurements. A significance level of $95 \%(P<0.05)$ was selected.

\section{RESULTS}

\section{Efficiency of copper removal by the biofilter}

Fig. 1(a) shows the mean amount of copper in the effluent water during three successive 10 day cycles of operation for a total of 30 days. The elimination of copper by the biofilter required a stabilization period of 10 days, after which the performance of the system remained constant with $90 \%$ removal of the metal from the groundwater. An increase of the $\mathrm{Cu}(\mathrm{II})$ concentration in effluent water up to $1.5 \mathrm{mg} \mathrm{l}^{-1}$ was observed during days 17-20 of the second cycle of operation, due to the saturation of the biofilm, which was corrected by the washing step. Fig. 1(b) shows the kinetics of $\mathrm{Cu}(\mathrm{II})$ removal from influent water during an extended period of time (7 months). During the whole experiment, a blue deposit of $\mathrm{Cu}(\mathrm{II})$ developed at the top horizon of the column, which became more apparent as the experiment progressed. At any time during the experiment, the intensity of the blue colour gradually decreased toward the bottom of the column. Analyses confirmed that copper was mostly retained at the top level of the biofilter bed $(<10 \mathrm{~cm})$ in all cycles. The system became increasingly saturated with metal and the efficiency of copper removal gradually decreased with time. After 200 days of operation, $73 \%$ of $\mathrm{Cu}(\mathrm{II})$ was being removed from the water.

\section{Biofilm structure and characterization of the sites of copper accumulation}

SEM images of the biofilm formed on control and copperexposed biofilters were taken at the four sampling ports of the column. They demonstrated a drastic effect of $\mathrm{Cu}$ (II) on biofilm morphology. Fig. 2 shows the distinct morphology 
(a)

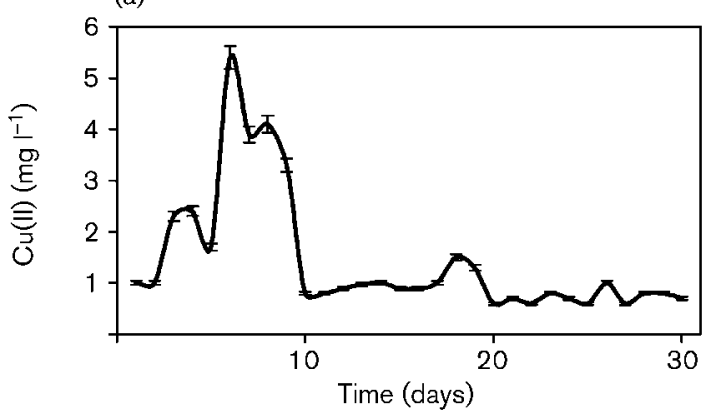

(b)

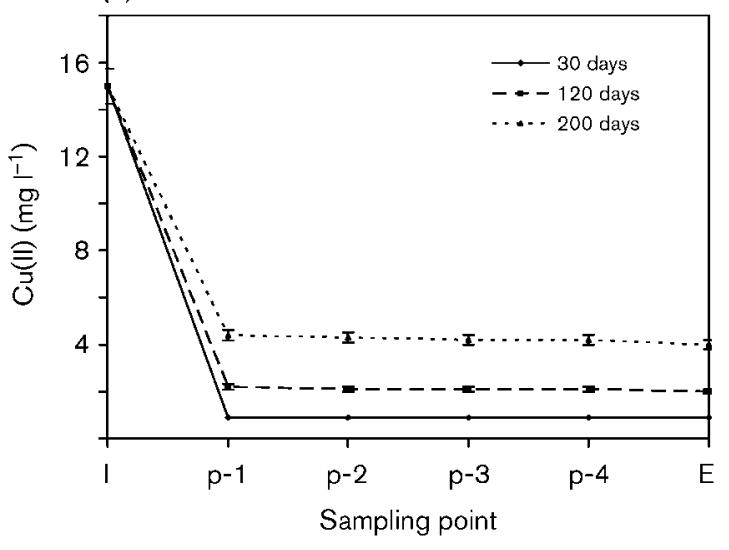

Fig. 1. Rate of copper removal by the biofilm. (a) Evolution of $\mathrm{Cu}(\mathrm{II})$ concentration $\left(\mathrm{mg} \mathrm{l}^{-1}\right)$ in effluent water during the first three cycles of operation of the biofilter. (b) Kinetics of copper removal from groundwater along the biofilter depth after 30, 120 and 200 days of operation. Bars show the SD of the mean $(n=3)$.

of the biofilm attached to the surface of the carrier material on the $\mathrm{Cu}(\mathrm{II})$-removing biofilter (Fig. 2b), compared to the control biofilm formed in the absence of $\mathrm{Cu}$ (II) (Fig. 2a). The images of the biofilms were taken from samples at $\mathrm{p}-1$ on day 9 of the cycle, 1 day before the washing of the column. While the control biofilm shows a heterogeneous population, formed by filamentous micro-organisms and bacteria of different morphologies with surrounding EPS, the $\mathrm{Cu}(\mathrm{II})$-exposed biofilm shows the surface of the carrier homogeneously covered with spherical aggregates of microorganisms, embedded in an abundant matrix of polymeric material. EDX analysis (Fig. 2e) shows a $\mathrm{Cu}$ peak $\left(K_{\alpha}=8 \mathrm{keV}\right)$ on the surface of the polysaccharide cell matrix. $\mathrm{Cu}(\mathrm{II})$ was detected by EDX at the other three sampled depths of the column, although in samples taken at $\mathrm{p}-4$, copper peaks detected were low, and the biofilm structure was more similar to that of control biofilm (data not shown).

Biofilm samples were also taken and analysed on day 1 of the operation cycle, to evaluate the effects of the washing step. SEM/EDX revealed that the EPS matrix was noticeably less saturated with metal at p-3 (compare Fig. $2 c$ and d), although copper was still detected by EDX in the biofilm (Fig. 2f).

TEM images of transverse sections of the spherical structures of the biofilm (Fig. 3a) showed the presence of bacillary cells embedded in the polymer (Fig. 3b). Analysis of electron-dense stained zones by EDX confirmed the bioaccumulation of copper in the polymeric matrix, as shown by the $\mathrm{Cu}$ peaks $\left(K_{\beta}=8.9 \mathrm{keV}\right)$. Eukaryotic cells were also found by the microscopic examination, which contained copper intracytoplasmically (Fig. 3c), while no $\mathrm{Cu}(\mathrm{II})$ was detected by EDX inside any prokaryotic cells observed by TEM. Detection of $\mathrm{P}\left(K_{\alpha}=2 \mathrm{keV}\right)$ and/or Si $\left(K_{\alpha}=1.74 \mathrm{keV}\right)$ suggests that $\mathrm{Cu}(\mathrm{II})$ accumulated by binding to phosphate or silicate.

\section{Physiology and biological activities of the biofilms}

The parameters used to monitor the physiology and biological activities of the two biofilters are summarized in Table 1. Data analysed were measurements from the third to the twelfth cycle, when the copper-exposed biofilter showed a stable removal rate of the heavy metal (see Fig. 1). All the parameters were measured during at least three complete cycles of operation and showed no significant temporal variation; thus, the mean values are reflected in Table 1.

When $\mathrm{Cu}$ (II) was present in the treated water, the content of organic matter was considerably higher at all depths of the biofilter column. This parameter did not vary significantly with sample location in either control or experimental biofilter. There was a $1 \log$ decrease in viable counts of mesophilic micro-organisms recovered from the $\mathrm{Cu}$ (II)exposed biofilter, compared to the control. The diversity of the colonial morphologies observed in plate counts was also clearly reduced in the presence of copper. Very similar colony types were found at the four depths of the biofilter.

The presence of $\mathrm{Cu}(\mathrm{II})$ in the influent water had a negative effect on the biological activities of the biofilm, as reflected by the severe reduction in ATP content, especially in the first $10 \mathrm{~cm}$ of the $\mathrm{Cu}(\mathrm{II})$-exposed biofilm (p-1). However, the ATP content recovered progressively through the column, reaching values similar to those of the control biofilm at the lower end of the column (p-4). Sucrose consumption by biofilm micro-organisms and alkaline phosphatase activity were also clearly depressed by copper at all depths of the biofilter.

\section{Analysis of EPS composition}

There were significant differences in the EPS composition between the two biofilters, as shown in Table 2. Total carbohydrate content and acetyl groups were considerably increased by the presence of $\mathrm{Cu}(\mathrm{II})$, while protein content was reduced $46 \%$. 

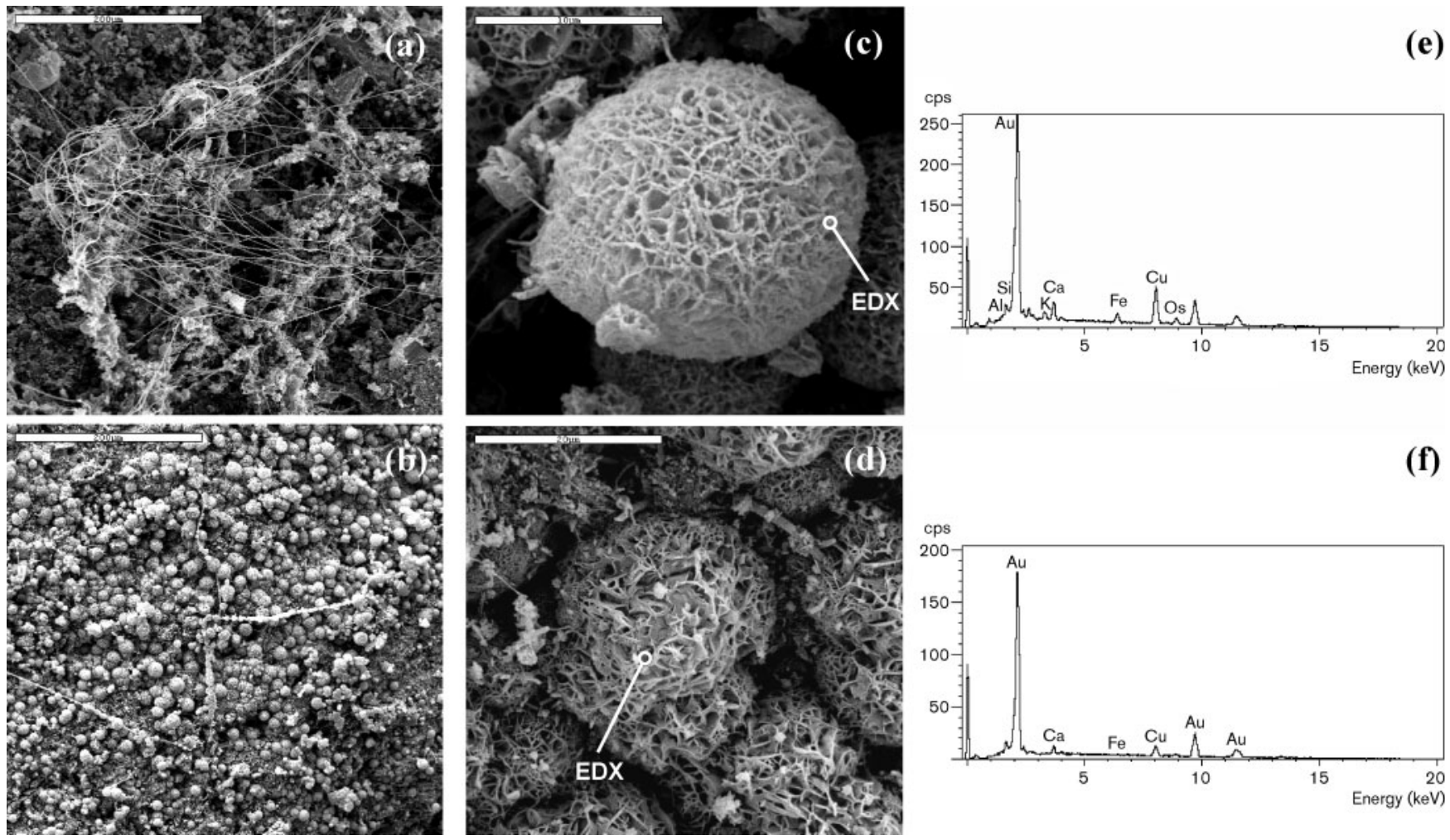

Fig. 2. SEM images (a-d) and EDX analysis (e-f) of $\mathrm{Cu}(\mathrm{II})$-removing biofilms. (a) Control biofilm, formed in absence of $\mathrm{Cu}(\mathrm{II})$, sampled at p-1 on day 9 of a cycle of operation (day before washing of the biofilter). Scale bar, $200 \mu \mathrm{m}$. (b) Biofilm formed in the presence of $15 \mathrm{mg} \mathrm{Cu}(\mathrm{II}) \mathrm{I}^{-1}$, sampled at $\mathrm{p}-1$ on day 9 of a cycle of operation (day before washing of the biofilter). Scale bar, $200 \mu \mathrm{m}$. Note the spherical biofilm aggregates formed on the surface of the carrier material, which were absent in the control biofilm. (c) Detail of (b) showing the spherical, sponge-like structure of aggregates. Scale bar, $10 \mu \mathrm{m}$. (d) Micrograph of unsaturated spherical biofilm aggregates formed on the surface of the carrier material at $p-3$ on day 1 of a cycle of operation (day after washing of the biofilter). Scale bar, $20 \mu \mathrm{m}$. Note that the aggregates are less saturated with metal, compared to micrograph (c). (e) EDX spectrum of the region circled in (c), showing the presence of copper. (f) EDX spectrum of the region circled in (d), showing the presence of copper. Aluminium, calcium, potassium, silicon and iron are also found on the carrier material (EDX data not shown). Gold and osmium occur due to the sample preparation process.

\section{Identification of major cultivable bacterial species in the biofilm}

As the colony types observed were very similar at the four depths of the biofilter, single colonies were selected from viable count plates of biofilms taken from sampling port $\mathrm{p}-1$, on the basis of their different morphologies, which were subsequently purified and identified by amplification and sequencing of the 16S rRNA gene. Seven major colony types were found. Their most probable taxonomic affiliations are shown in Table 3. The colony type corresponding to isolate $\mathrm{Cu}-\mathrm{E}$, identified as Sphingomonas sp., was dominant in all plate counts and frequently outnumbered the other major colony types by at least two logarithmic units. V3-region amplicons of the seven strains yielded completely different TGGE fingerprints, except for strains D and J, which were both affiliated to the genus Pseudomonas and migrated at the same distance in the gel (not shown). The V3 region of both strains had identical nucleotide sequence. All isolates yielded a single TGGE band.

\section{Temporal and spatial variation of TGGE community profiles in the copper-removing biofilter}

Clustering of the TGGE profiles demonstrated that the community composition in the control biofilter significantly differed from that of the column in which $\mathrm{Cu}(\mathrm{II})$ was being removed from polluted water (Fig. 4). Samples were taken at four different depths in each biofilter, showing that in all cases there was little spatial variation of the bacterial diversity within the column. In the $\mathrm{Cu}(\mathrm{II})$-exposed biofilter, DNA was extracted from samples taken after 90 and 121 days of operation. The fingerprints of both samplings clustered at over $70 \%$ similarity, the major temporal difference observed being a change in the relative intensity of some of the TGGE bands. 

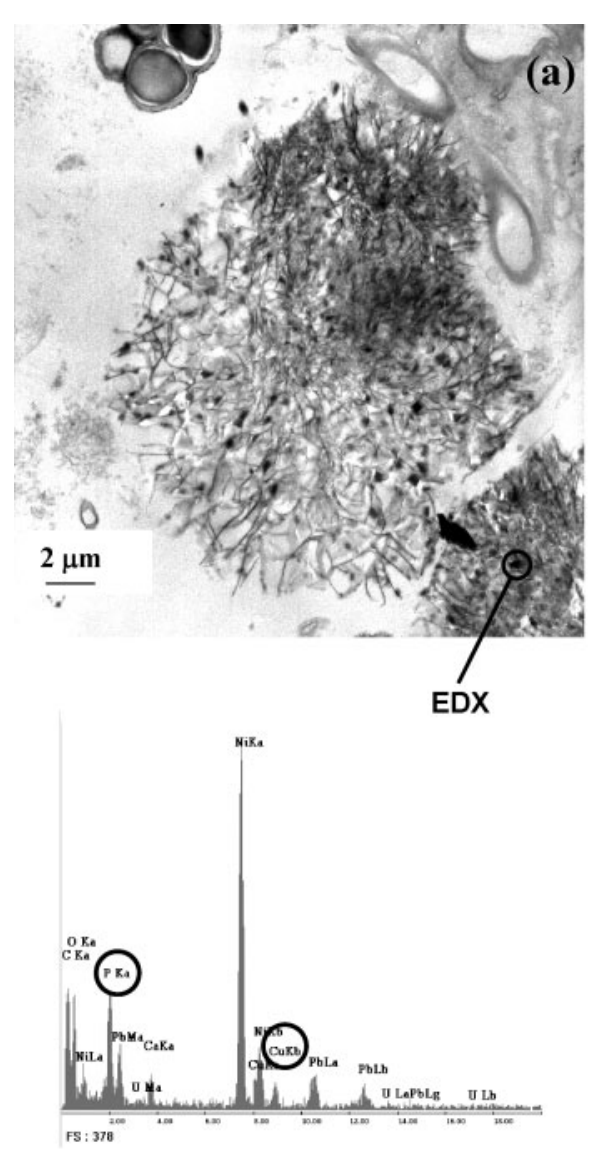
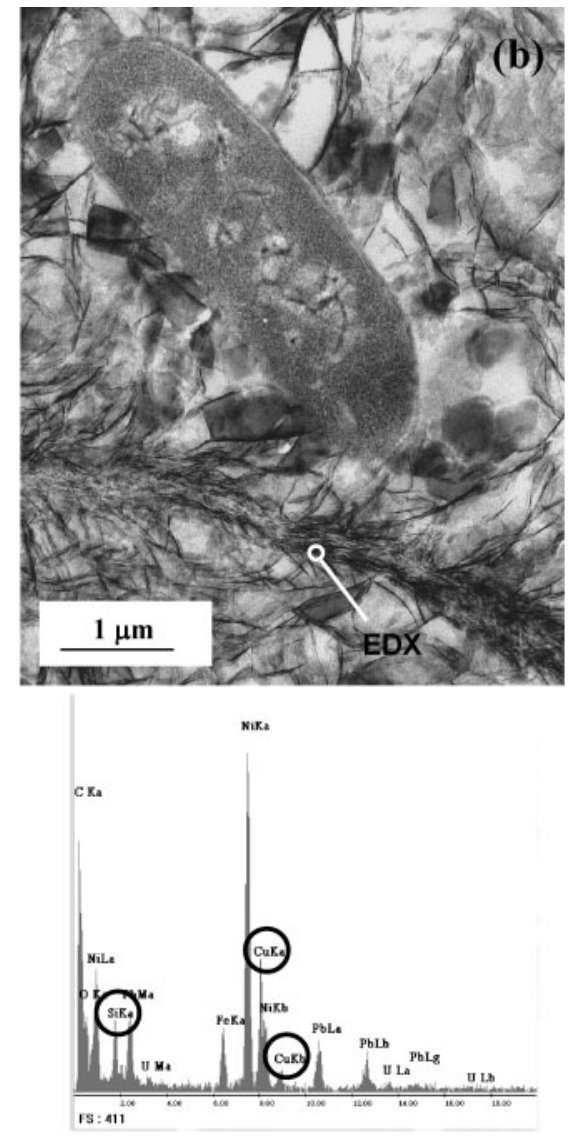
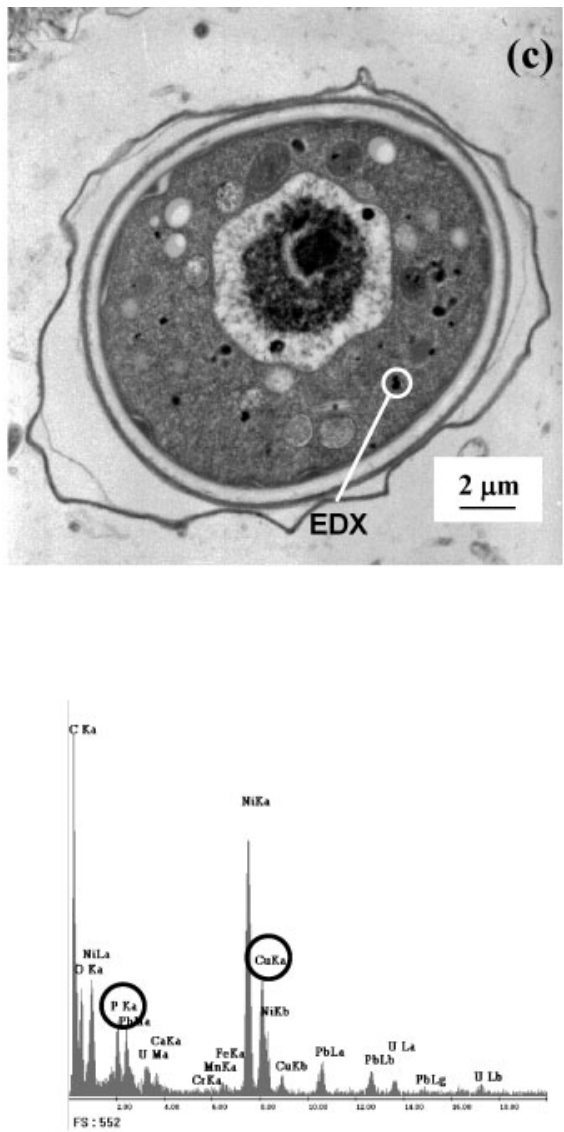

Fig. 3. TEM micrographs showing thin sections of the biofilm and the distribution of copper by the respective EDX. (a) Thin transverse section of biofilm aggregates shown in Fig. 2(b) and EDX analysis confirming the presence of $\mathrm{Cu}(\mathrm{II})$, silicon and phosphorus. (b) Detail of a bacillary cell and polymer fibres associated with $\mathrm{Cu}(\mathrm{II})$. (c) Eukaryotic cell carrying copper intracellularly. Lead and uranium occur as a result of the sample preparation process. Nickel was the grid material.

Table 1. Chemical and microbiological characterization of biofilms formed in the laboratory-scale biofilter, in the presence or absence of $\mathrm{Cu}(\mathrm{II})$

\begin{tabular}{|c|c|c|c|c|c|}
\hline Parameter ${ }^{\star}$ & Biofilter & \multicolumn{4}{|c|}{ Sampling port } \\
\hline \multirow[t]{2}{*}{ Organic matter [mg weight volatiles (g dry carrier material $)^{-1}$ ] } & Control & 37.8 & 40.0 & 34.8 & 27.5 \\
\hline & $\mathrm{Cu}(\mathrm{II})$ & $68.2 \dagger$ & $67.9 \dagger$ & $57.9 \dagger$ & $57.1 \dagger$ \\
\hline \multirow[t]{2}{*}{ Mesophile counts [log c.f.u. (mg organic matter) ${ }^{-1}$ ] } & Control & 7.81 & 7.82 & 7.65 & 7.84 \\
\hline & $\mathrm{Cu}(\mathrm{II})$ & 6.95 & $6.37 \dagger$ & $6.41 \dagger$ & $6.53 \dagger$ \\
\hline \multirow[t]{2}{*}{ Total alkaline phosphatase activity [mg $p$-nitrophenol $(\mathrm{mg} \text { organic matter })^{-1} \mathrm{~h}^{-1}$ ] } & Control & 350 & 170 & 320 & 500 \\
\hline & $\mathrm{Cu}(\mathrm{II})$ & $24 \dagger$ & $31 \dagger$ & $37 \dagger$ & $40 \dagger$ \\
\hline \multirow[t]{2}{*}{ Sucrose concentration in effluent water [mg sucrose $\left.(1 \text { effluent water })^{-1}\right]$} & Control & 67.5 & 62.1 & 23.1 & 13.14 \\
\hline & $\mathrm{Cu}(\mathrm{II})$ & $58.0 \dagger$ & $54.7 \dagger$ & $47.6 \dagger$ & $45.0 \dagger$ \\
\hline
\end{tabular}

${ }^{*}$ Values of all parameters are the mean of nine measurements. Three biological samples were used, with three replicated measures of each one. $\dagger$ Denotes a significant difference compared to control $(P<0.05)$. 
Table 2. Mean composition of EPS recovered from control and $\mathrm{Cu}(\mathrm{II})$-exposed biofilms

\begin{tabular}{|lcc|}
\hline & \multicolumn{2}{c|}{$\begin{array}{c}\text { Amount of component } \\
{\left[\mathbf{g}(\mathbf{1 0 0} \text { g EPS })^{-1} \text { ] }\right.}\end{array}$} \\
\cline { 2 - 3 } & Control & Copper biofilter \\
\hline Organic matter (weight & 97 & 95 \\
of volatile compounds) & & \\
Total carbohydrates & 39.7 & 54.5 \\
Total proteins & 4.6 & $2.5^{\star}$ \\
Uronic acids & 12.1 & 13.9 \\
Acetyl groups & 2.6 & $3.2^{\star}$ \\
\hline
\end{tabular}

${ }^{\star}$ Denotes a significant difference compared to control $(P<0.05)$.

\section{Phylogeny of major bacterial species, inferred from the partial 16S rRNA gene sequence}

In order to get further insight into the species composition of the $\mathrm{Cu}(\mathrm{II})$-exposed biofilter, 14 bands were reamplified and sequenced from the TGGE gel (Fig. 4) and their phylogenetic affiliations are shown in Fig. 5. Most of the analysed bands had closest relatives frequently inhabiting aquatic habitats, with the majority of sequences $(78 \%)$ affiliated to alphaproteobacteria of the Sphingomonadaceae. The sequence of TGGE band no. 14 was $98 \%$ identical to the environmental clone AF445657, but it is phylogenetically distant from any validated bacterial taxon, Propionibacterium acidipropionici being the nearest described relative, at only $80 \%$ identity.

TGGE fingerprints of $16 \mathrm{~S}$ rRNA from the seven cultivable strains did not match those obtained from the amplification of community DNA, with the exception of the strain $\mathrm{Cu}-\mathrm{E}$ sequence, which had the same electrophoretic behaviour and identical nucleotide sequence as TGGE band 5 (data not shown). None of the other major types of cultivable bacterial species identified was found amongst the TGGE bands which were sequenced. Their relative abundance may be below the detection limit of TGGE (estimated around $1 \%$ ), as supported by the results of plate counts.

\section{DISCUSSION}

Experiments carried out under controlled conditions are essential to verify the impact of pollutants on microbial ecosystems (Lawrence et al., 2004). In this study, the combination of different microbiological, analytic, microscopic and molecular techniques allowed the characterization of the biological adaptation of the microbial biofilm and the evolution of its community composition in response to copper stress in a laboratory-scale aerobic biofilter designed for the decontamination of groundwater polluted with $\mathrm{Cu}(\mathrm{II})$.

The biofilter system was efficient and fulfilled a performance analogous to other described technologies for the bioremediation of heavy metals from water (Costley \& Wallis, 2001; Leonhäuser et al., 2006; Malik, 2004). After one initial phase of unstable biofilter efficiency (first 10 day cycle of operation), possibly due to the adaptation of the microbiota to the new milieu, the submerged fixed biofilm succeeded in the removal of up to $90 \%$ of $\mathrm{Cu}$ (II) when it was working in continuous mode for a period over 200 days. The analysis of the copper concentration profile along the filter column length demonstrated that most of the heavy metal was effectively retained in the first $10 \mathrm{~cm}$ of the filter bed (Fig. 1). Although a change in dimensions of the biofilter could be considered, full-scale process operation with real wastes has shown that overdesign contributes to improved adaptation of biologically based heavy metal removal under different operating conditions and overload episodes (Leonhäuser et al., 2006).

Introduction of copper in groundwater induced marked physiological and structural changes in the biofilm microbial communities of the biofilter used in the study, as was previously reported for biofilms formed naturally on freshwater surfaces (Massieux et al., 2004). SEM images of the copper-removing biofilter revealed dramatic differences of the biofilm appearance compared to the control biofilter. $\mathrm{Cu}(\mathrm{II})$ induced a densely packed structure of the bacterial aggregates in the biofilm, and the development of a thick EPS matrix enveloping the cells. TEM and EDX analysis localized copper ions in EPS fibres (Fig. 3), verifying that $\mathrm{Cu}(\mathrm{II})$ removal from water takes place through interaction

Table 3. Identification of strains representative of the dominant cultivable colony types in the copper-exposed biofilm, based on the partial sequence of their 16S rRNA genes

\begin{tabular}{|llll|}
\hline Isolate name & \multicolumn{1}{c}{$\begin{array}{c}\text { Closest taxonomic affiliation } \\
\text { (class/family) }\end{array}$} & $\begin{array}{c}\text { Overlap } \\
(\mathbf{n t})\end{array}$ & $\begin{array}{c}\text { Most similar described organism } \\
\text { and database acc. no. }\end{array}$ \\
\hline $\mathrm{Cu}-\mathrm{B}$ & Gammaproteobacteria/Moraxellaceae & 1469 & Acinetobacter lwoffii (AY176770) \\
$\mathrm{Cu}-\mathrm{C}$ & Firmicutes/Bacillaceae & 1469 & Exiguobacterium sp. (AY745850) \\
$\mathrm{Cu}-\mathrm{D}$ & Gammaproteobacteria/Pseudomonadaceae & 1484 & Pseudomonas alcaliphila (AB030583) \\
$\mathrm{Cu}-\mathrm{E}$ & Alphaproteobacteria/Sphingomonadaceae & 1410 & Sphingomonas sp. (AJ575818) \\
$\mathrm{Cu}-\mathrm{F}$ & Firmicutes/Bacillaceae & 1498 & Bacillus cereus (AM062683) \\
$\mathrm{Cu}-\mathrm{I}$ & Firmicutes/Staphylococcaceae & 1408 & Staphylococcus haemolyticus (D83367) \\
$\mathrm{Cu}-\mathrm{J}$ & Gammaproteobacteria/Pseudomonadaceae & 1442 & Pseudomonas mendocina (DQ178222) \\
\hline
\end{tabular}




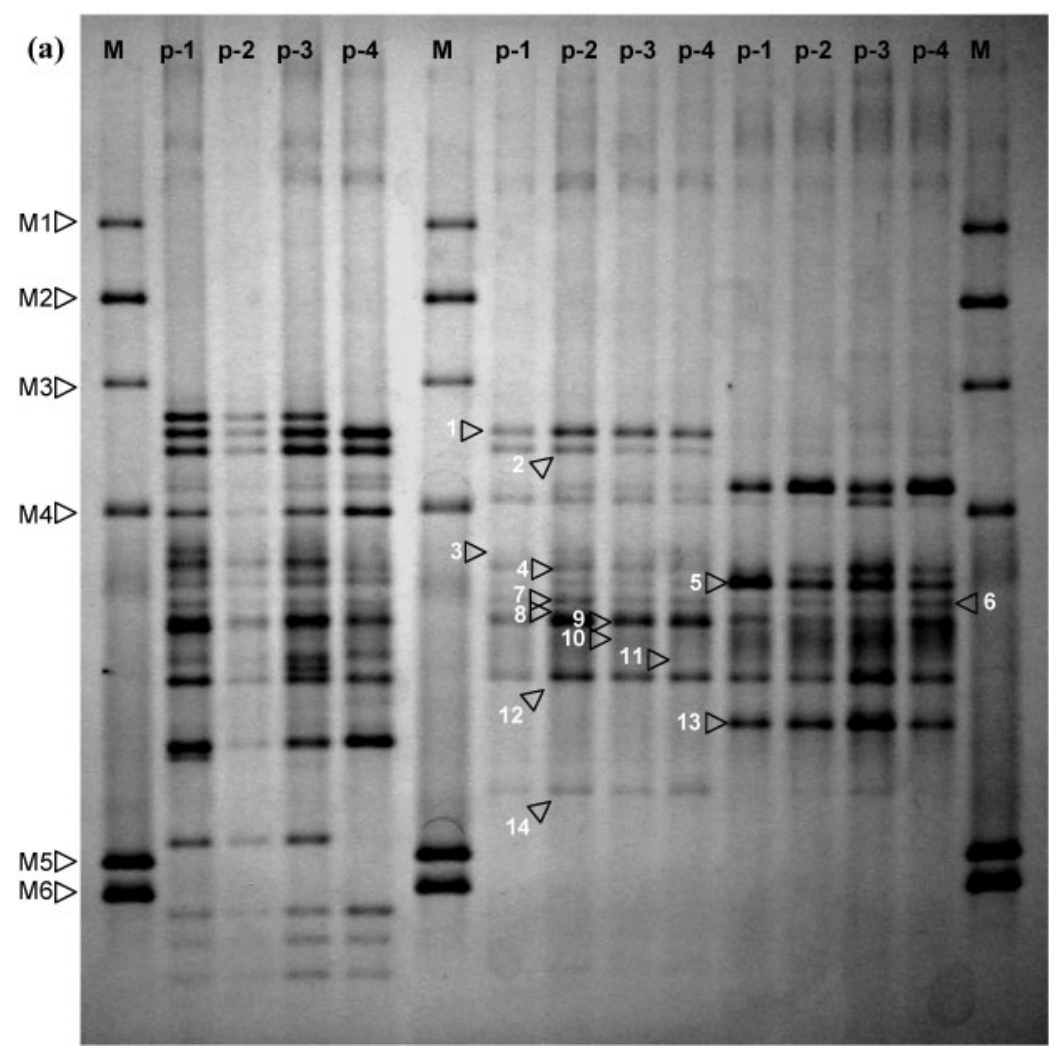

$\begin{array}{llllll}50 \% & 60 \% & 70 \% & 80 \% & 90 \% & 100 \%\end{array}$

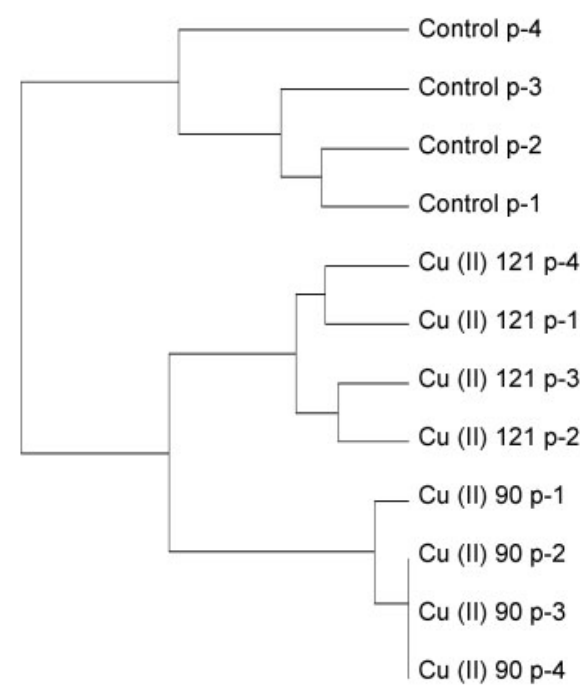

Fig. 4. (a) TGGE community profiles of biofilms samples taken from control and $\mathrm{Cu}(\mathrm{II})$-exposed biofilters. Profiles are based on amplification and separation of the V3-hypervariable region of the 16S rRNA gene. Numbered arrows point to bands that were reamplified and sequenced for the phylogenetic analysis shown in Fig. 5. The time and point of sampling in the Cu(II) biofilm is indicated above each lane. $\mathrm{M}$, six-species marker, made by amplification of V3 region from DNA of the following culture collection strains: M1, Staphylococcus aureus ATCC 25923; M2, Pseudomonas putida ATCC 8750; M3, Acinetobacter calcoaceticus ATCC 15308; M4, Escherichia coli DH5 $\alpha$; M5, Nocardia corynebacterioides ATCC 21253; M6, Micrococcus luteus ATCC 9341. (b) UPGMA cluster analysis of TGGE banding profiles.

with the bacterial exopolymers. Bacterial extracellular polymers were also found responsible for the metal-binding ability of biofilms grown in a rotating biological contactor in the presence of copper and other heavy metals (Costley \& Wallis, 2001). Although the present study did not demonstrate the involvement of the bacterial cell surfaces in metal removal, metals ions can also bind to electronegative sites of the lipopolysaccharide, phospholipids and other molecules (Bruins et al., 2000; Ferris, 1989); hence it is possible that part of the $\mathrm{Cu}(\mathrm{II})$ from the water could also have become bound to the cell walls of some or all of the organisms in the biofilm.

TEM and EDX analysis did not show $\mathrm{Cu}(\mathrm{II})$ inside the bacterial cells. By contrast, eukaryotic cells were observed in the biofilter which accumulated copper inside the cytoplasm (Fig. 3). Intracellular sequestration of metals by eukaryotic micro-organisms, such as yeasts and algae, is often achieved in this manner (Malik, 2004). Most studies on the remediation of heavy metals by live cells describe a biphasic mechanism, which starts with a rapid biosorption process followed by a slower, metabolic active uptake of the metal (Malik, 2004). In both, eukaryotes and bacteria (i.e. cyanobacteria and Pseudomonas spp.), intracellular metals often bind to specific low molecular mass proteins (metallothioneins), or to polyphosphate granules (Blindauer et al., 2002; Malik, 2004; Rutheford \& Bird, 2004).

The effects of $\mathrm{Cu}(\mathrm{II})$ on the biofilm were reflected in the depression of sucrose consumption by the micro-organisms, and the significant reduction of the ATP content of the biomass and of the alkaline phosphatase activity (Table 1). A direct correlation was evident between ATP decrease and the level of copper accumulation, because especially low values of ATP per $g$ biofilm biomass were recorded in the first $10 \mathrm{~cm}$ of the biofilter (Table 1), where major retention of the heavy metal took place (Fig. 1). It is possible that the inhibition of sucrose uptake and the reduction of alkaline phosphatase activity, together with the accumulation of phosphorus in copper-bound polyphosphates, contributed 


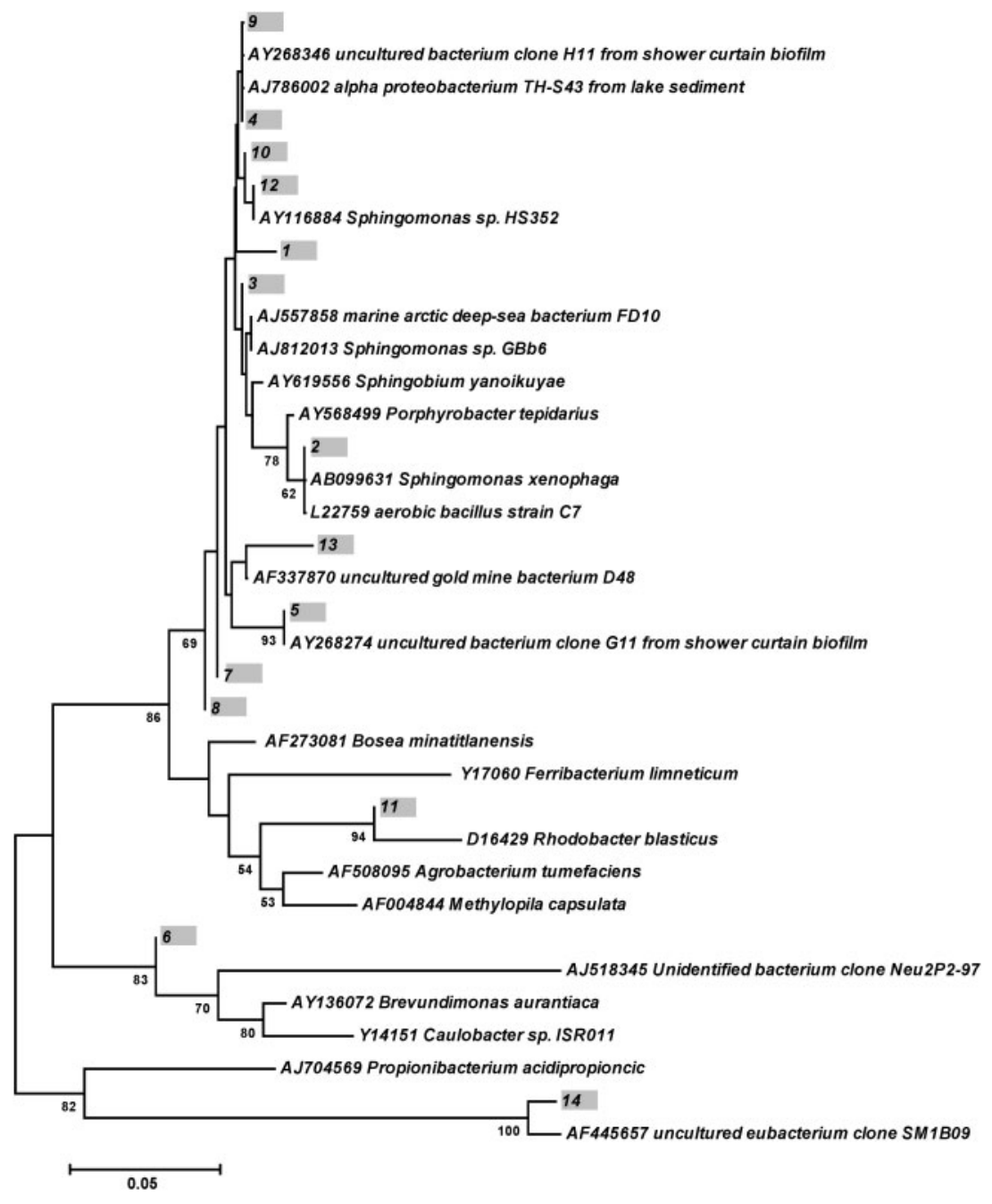

Fig. 5. Phylogenetic neighbour-joining tree of $16 \mathrm{~S}$ rRNA gene partial sequences (V3-hypervariable region) showing the affiliations of 14 sequences amplified from excised TGGE bands (see Fig. 4). Accession numbers of bacteria retrieved from the EMBL database are indicated in the tree. Only bootstrap values above $50 \%$ are shown.

to energy and phosphorus deprivation of cells, potentially leading to the decrease in ATP synthesis. Additionally, copper efflux in bacteria is often mediated in an energydependent manner by $\mathrm{Cu}(\mathrm{I})$ translocating P-type ATPases (Gatti et al., 2000). Eukaryotes, including yeasts, plants and humans, possess similar ATPases involved in maintenance of copper homeostasis (Rensing \& Grass, 2003; Rosen, 2002). Copper-stressed micro-organisms thus may experience an extra ATP demand to extrude copper ions from the cytoplasm. The possible implication of such efflux mechanisms was beyond the aim of the present study and was not further investigated.

Enzymic activities are a good indicator of toxicity of heavy metals, which inhibit enzymic reactions mainly by blocking the functional groups of enzymes, or reacting with enzymesubstrate complexes (Speir et al., 1995). Alkaline phosphatase activity is common in aquatic ecosystems and is especially sensitive to $\mathrm{Cu}(\mathrm{II})$ ions (Dohelman \& Haanstra, 1989; Renella et al., 2003). Cu(II) also inhibits acid phosphatase activities and alters its kinetics in soil (Huang \& Shindo, 2000; Renella et al., 2003). The inhibition of phosphatases can influence community composition under a heavy metal stress, because specific phosphatases are involved in the immobilization of heavy metals and metalloids by certain bacteria by precipitating them as phosphates outside the cells (Valls \& De Lorenzo, 2002). Inhibition of phosphatases, and resultant blocking of this protective mechanism in selected organisms, is proposed as the cause of the synergistic interaction of $\mathrm{Cu}$ (II) on the toxicity of other heavy metals such as Cd(II) in soils (Renella et al., 2003).

Metal immobilization by creating a permeability barrier is a common mechanism developed by bacteria to avoid metal toxicity, which often involves the non-specific binding of 
metal ions to natural molecules with ion-exchange properties in the outer membrane or envelope, and thus alterations of the cell wall, membrane or EPS can take place (Bruins et al., 2000). EPS produced by bacteria frequently is responsible for biosorption of metals, providing sites for the binding of cations, and helping to protect the cells from damage (Bruins et al., 2000; Costley \& Wallis, 2001; Teitzel \& Parsek, 2003; Valls \& De Lorenzo, 2002). Copper-resistant bacteria often produce large quantities of EPS (Turpeinen $e t$ al., 2004). Compared to the control treatment, the EPS composition of biofilms formed in the biofilter used in this study was altered in response to $\mathrm{Cu}(\mathrm{II})$, which drastically modified the carbohydrate/protein ratio (Table 2). Few data are available on the effect of heavy metals on biofilm EPS. Changes in exopolymer structure, abundance and composition are reported to be commonly induced by heavy metal stress in biofilms; however, the changes do not follow a universal pattern. Marine biofilms increase EPS production in response to several heavy metals, including copper (Fang et al., 2002), while EPS content of river biofilms substantially declines on exposure to $\mathrm{Ni}(\mathrm{II})$ (Lawrence et al., 2004). The carbohydrate/protein ratio is frequently altered by heavy metals, but the changes observed vary widely in different studies (Jang et al., 2001; Lawrence et al., 2004). Modifications in EPS composition of biofilms are attributed to the selective pressure of the heavy metals on the community, which favours bacterial populations producing an EPS having the characteristics that confer resistance to a particular metal ion (Lawrence et al., 2004).

Metal stress results in decreased microbial diversity (Turpeinen et al., 2004). Copper often inhibits microorganisms, inducing the viable-but-non-cultivable condition (Ordax et al., 2006; Rensing \& Grass, 2003); hence, cultivation-independent methods are required for the adequate study of the biological diversity of ecosystems exposed to high concentrations of this pollutant. In the submerged filter biofilm exposed to $\mathrm{Cu}(\mathrm{II})$, plate counts and identification of cultivable strains revealed a low bacterial diversity, with a predominant colony type related to the genus Sphingomonas. TGGE fingerprints also displayed a significant effect of the addition of $\mathrm{Cu}(\mathrm{II})$ to influent water on the composition of the bacterial community in the biofilm (Fig. 5). In two separate samplings from the $\mathrm{Cu}(\mathrm{II})$ exposed biofilm (cycles 9 and 12 of operation), few changes of the TGGE profile were observed. Although major retention of the heavy metal was taking place in the upper $10 \mathrm{~cm}$ of the filter bed, the analysis of spatial variation in biofilms by TGGE showed no significant changes on the biological diversity along the biofilter depth (Fig. 5). Previous studies have shown that heavy metals and other toxic compounds exert a selection pressure that influences community composition in aquatic biofilms (Lawrence et al., 2004). Studies based on FISH analysis (Principi et al., 2006) demonstrated that copper decreases the diversity of betaproteobacteria in wastewater-activated sludge, and DGGE profiling of biofilms formed in the presence of copper pointed to drastic changes of species composition induced by this heavy metal (Boivin et al., 2005; Massieux et al., 2004). However, few attempts have been made to date to identify taxonomically the major components of aquatic biofilm communities exposed to copper. TGGE fingerprinting coupled to sequence analysis is a method of choice for the rapid identification of dominant populations in such aquatic biofilms (Brümmer et al., 2003). In the biofilter used in this study, the prevalence of Sphingomonas-related bacteria was revealed by post-TGGE amplification and sequencing of $16 \mathrm{~S}$ rRNA gene V3-region amplicons. These data, together with the identification of Sphingomonas sp. as the major cultivable colony type in plate counts, confirmed a major role of these organisms in the composition of the $\mathrm{Cu}(\mathrm{II})$-removing community.

Sphingomonads are ubiquitous in freshwaters, wastewater and marine environments (Balkwill et al., 2003; White et al., 1995) and are well known for their ability to induce corrosion on copper tubing used in plumbing systems, releasing high concentrations of $\mathrm{Cu}(\mathrm{II})$ to the water running through the systems (Balkwill et al., 2003; Critchley et al., 2003, 2004). Sphingomonads have been also identified as major populations in biofilms formed in naturally nickelpolluted river water (Lawrence et al., 2004). These bacteria lack special growth requirements, grow easily in nutrientlimited environments, and produce abundant EPS (Balkwill et al., 2003; White et al., 1995), characteristics which are advantageous to growth and formation of stable biofilms in submerged biofilters. However, the exploitation of the potential of sphingomonads for the bioremediation of $\mathrm{Cu}(\mathrm{II})$ or other heavy metals from water is not often reported in the literature, and their mechanisms for resistance to $\mathrm{Cu}(\mathrm{II}), \mathrm{Ni}(\mathrm{II})$, or other heavy metals have not been investigated in depth. The results of this work have demonstrated the importance of Sphingomonas-like bacteria in the retention of copper by the biofilter technology, and their potential utility for the inoculation of systems designed for the removal of heavy metal ions from water. Future research will focus on the specific in situ quantification of these organisms in the biofilters by FISH, and the selection of $\mathrm{Cu}-$ (II)-bioaccumulating cultivable Sphingomonas-like strains to study their copper-resistance mechanisms in detail.

\section{ACKNOWLEDGEMENTS}

This work was funded by Confederación Hidrográfica del Guadalquivir (CHG, Sevilla, Spain), which provided financial support for the research, and a PhD scholarship to R. Vílchez. C. Pozo was funded by Programa de Retorno de Investigadores (Junta de Andalucía, Spain). B. Rodelas was funded by Programa Ramón y Cajal (MEC, Spain). The authors are very grateful to I. Wagner-Döbler (Helmholtz Center for Infection Research, Braunschweig, Germany) for her critical review of the manuscript, providing helpful comments and suggestions for its improvement. We also wish to thank the skilled technical assistance of J. Santamarina Urbano and A. Lario (DNA Sequencing Service, I. Parasitología y Bioquímica Lopez-Neyra, CSIC, Granada), C. Hernández Castillo, I. Guerra Tschuschke and M. Abad Ortega (SEM, TEM and EDX, Centro de Instrumentación Científica, U. de Granada). 


\section{REFERENCES}

Altschul, S. F., Madden, T. L., Schaeffer, A. A., Zhang, J., Zhang, Z., Miller, W. \& Lipman, D. J. (1997). Gapped BLAST and PSI-BLAST: a new generation of protein database search programs. Nucleic Acids Res 25, 3389-3402.

APHA (2001). Standard Methods for the Examination of Water and Wastewater, 20th edn. Edited by L. S. Clesceri, A. E. Greenberg \& A. D. Eaton. Washington DC: American Public Health Association.

Balkwill, D. L., Fredrickson, J. K. \& Romine, M. F. (2003). Sphingomonas and related genera. In The Prokaryotes: an Evolving Electronic Resource for the Microbiological Community, 3rd edn, release 3.14. 31/07/2003. Edited by M. Dworkin and others. New York: Springer.

Berman, T. (1970). Alkaline phosphatases and phosphorus availability in Lake Kinneret. Limnol Oceanogr 15, 663-674.

Blindauer, C. A., Harrison, M. D., Robinson, A. K., Parkinson, J. A., Bowness, P. W., Sadler, P. J. \& Robinson, N. J. (2002). Multiple bacteria encode metallothioneins and SmtA-like zinc fingers. $\mathrm{Mol}$ Microbiol 45, 1421-1432.

Blumenkrantz, N. \& Asboe-Hansen, G. (1973). New method for quantitative determination of uronic acids. Anal Biochem 54, 484-489.

Boivin, M. E. Y., Massieux, B., Breure, A. M., Van Den Ende, F. P., Greve, G. D., Rutgers, M. \& Admiraal, W. (2005). Effects of copper and temperature on aquatic bacterial communities. Aquat Microbiol 71, 345-356.

Bradford, M. M. (1976). A rapid and sensitive method for the quantification of microgram quantities of protein utilising the principle of protein-dye binding. Anal Biochem 72, 248-254.

Bruins, M. R., Kapil, S. \& Ochme, F. W. (2000). Microbial resistance to metals in the environment. Ecotoxicol Environ Safety 45, 198-207.

Brümmer, I. H. M., Felske, A. \& Wagner-Döbler, I. (2003). Diversity and seasonal variability of $\beta$-Proteobacteria in biofilms of polluted rivers: analysis by temperature-gradient gel electrophoresis and cloning. Appl Environ Microbiol 69, 4463-4473.

Cameron, R. E. (1992). Guide to Site and Soil Description for Hazardous Waste Site Characterization, vol. 1, Metals. Environmental Protection Agency EPA/600/4-91/029.

Costley, S. C. \& Wallis, F. M. (2001). Bioremediation of heavy metals in a synthetic wastewater using a rotating biological contactor. Water Res 35, 3715-3723.

Critchley, M. M., Cromar, N. J., McClure, N. C. \& Fallowfield, H. J. (2003). The influence of the chemical composition of drinking water on cuprosolvency by biofilm bacteria. J Appl Microbiol 94, 501-507.

Critchley, M. M., Pasetto, R. \& O'Halloran, R. J. (2004). Microbiological influences in "blue water" copper corrosion. J Appl Microbiol 97, 590-597.

Dean, W. E. (1974). Determination of carbonate and organic matter in calcareous sediments and sedimentary rocks by loss on ignition: comparison with other methods. J Sedim Petrol 44, 242-248.

Dohelman, P. \& Haanstra, L. (1989). Short- and long-term effects of heavy metals on phosphatase activity: an ecological dose-response model approach. Biol Fertility Soils 8, 235-241.

Dubois, M., Gilles, K. A., Hamilton, J. K., Rebers, P. A. \& Smith, F. (1956). Colorimetric method for determination of sugars and related substances. Anal Chem 28, 350-356.

Eccles, H. (1999). Treatment of metal-contaminated wastes: why select a biological process? Trends Biotechnol 17, 462-465.

Fang, H. H. P., Xu, L. C. \& Chan, K. Y. (2002). Effects of toxic metals and chemicals on biofilm and biocorrosion. Water Res 36, 4709-4716.
Ferris, F. G. (1989). Metallic ion interactions with the outer membrane of Gram-negative bacteria. In Metal Ions and Bacteria, pp. 295-323. Edited by T. J. Beveridge \& R. J. Doyle. New York: Wiley.

Fraga, C. G. (2005). Relevance, essentiality and toxicity of trace elements in human health. Mol Aspects Med 26, 235-244.

Gatti, D., Mitra, B. \& Rosen, B. P. (2000). Escherichia coli soft metal ion-translocating ATPases. J Biol Chem 275, 34009-34012.

Gómez, M. A., Hontoria, E. \& González-López, J. (2002). Effect of dissolved oxygen concentration on nitrate removal from groundwater using a denitrifying submerged filter. $J$ Hazard Mater 90, 267-278.

Hotz, C., Lowe, N. M., Araya, M. \& Brown, K. H. (2003). Assessment of the trace element status of individuals and populations: the example of zinc and copper. J Nutr 133, 1563-1568.

Huang, Q. \& Shindo, H. (2000). Effects of copper on the activity and kinetics of free and immobilized acid phosphatase. Soil Biol Biochem 32, 1885-1892.

Jang, A., Kim, S. M., Kim, S. Y., Lee, S. G. \& Kim, I. S. (2001). Effect of heavy metals $(\mathrm{Cu}, \mathrm{Pb}, \mathrm{Ni})$ on the composition of EPS in biofilms. Water Sci Technol 43, 41-48.

Jeanmougin, F., Thompson, J. D., Gouy, M., Higgins, D. G. \& Gibson, T. J. (1998). Multiple sequence alignment with Clustal X. Trends Biochem Sci 23, 403-405.

Karl, D. M. (1980). Cellular nucleotide measurements and application in microbial ecology. Microbiol Rev 44, 739-796.

Kumar, S., Tamura, K., Jakobsen, I. B. \& Nei, M. (2001). MEGA2: Molecular Evolutionary Genetics Analysis software, Arizona State University, Tempe, Arizona, USA.

Lawrence, J. R., Chenier, M. R., Roy, R., Beaumier, D., Fortin, N., Swerhorne, G. D. W., Neu, T. R. \& Greer, C. W. (2004). Microscale and molecular assessment of impacts of nickel, nutrients and oxygen level on structure and function of river biofilm communities. Appl Environ Microbiol 70, 4326-4339.

Leonhäuser, J., Röhricht, M., Wagner-Döbler, I. \& Deckwer, W. D. (2006). Reaction engineering aspects of microbial mercury removal. Eng Life Sci 6, 139-148.

Malik, A. (2004). Metal bioremediation through growing cells. Environ Int 30, 261-278.

Massieux, B., Boivin, M. E. Y., Van Den Ende, F. P., Langenskiöld, J., Marvan, P., Barrenguet, C., Admiraal, W., Laanbroek, H. J. \& Zwart, G. (2004). Analysis of structural and physiological profiles to assess the effects of $\mathrm{Cu}$ on biofilm microbial communities. Appl Environ Microbiol 70, 4512-4521.

McComb, E. A. \& McCready, R. M. (1957). Determination of acetyl in pectin and acetylated carbohydrate polymers. Anal Chem 29, 819-821.

Mulligan, C. N., Yong, R. N. \& Gibbs, B. F. (2001). Remediation technologies for metal-contaminated soils and groundwater: an evaluation. Eng Geology 60, 193-207.

Muyzer, G., De Waal, E. C. \& Uitterlinden, A. G. (1993). Profiling of complex microbial populations by denaturing gradient gel electrophoresis analysis of polymerase chain reaction amplified genes coding for 16S RNA. Appl Environ Microbiol 59, 695-700.

Nicolaisen, M. H. \& Ramsing, N. B. (2002). Denaturing gradient gel electrophoresis (DGGE) approaches to study the diversity of ammonia-oxidizing bacteria. J Microbiol Methods 50, 189-203.

Nielsen, P. \& Jahn, A. (2002). Extraction of EPS. In Microbial Extracellular Polymeric Substances. Characterization, Structure and Function, pp. 49-71. Edited by J. Winderg, J. Neu \& H. Flemming. Berlin: Springer. 
Ordax, M., Marco-Noales, E., López, M. M. \& Biosca, E. G. (2006). Survival strategy of Erwinia amylovora against copper: induction of the viable-but-nonculturable state. Appl Environ Microbiol 72, 3482-3488.

Pozo, C., Rodelas, B., De La Escalera, S. \& González-López, J. (2002). D,L-Hydantoinase activity of an Ochrobactrum anthropi strain. J Appl Microbiol 92, 1028-1034.

Principi, P., Villa, F., Bernasconi, M. \& Zanardini, E. (2006). Metal toxicity in municipal wastewater activated sludge investigated by multivariate analysis and in situ hybridization. Water Res 40, 99-106.

Renella, G., Ortigoza, A. L. R., Landi, P. \& Nannipieri, P. (2003). Additive effects of copper and zinc on cadmium toxicity on phosphatase activities and ATP content of soil as estimated by the ecological dose $\left(\mathrm{ED}_{50}\right)$. Soil Biol Biochem 35, 1203-1210.

Rensing, C. \& Grass, G. (2003). Escherichia coli mechanisms of copper homeostasis in a changing environment. FEMS Microbiol Rev 27, 197-213.

Roe, J. H. \& Papadopoulos, N. M. (1954). The determination of fructose-6-phosphate and fructose-1,6-diphosphate. J Biol Chem 210, 703-707.

Rosen, B. P. (2002). Transport and detoxification systems for transition metals, heavy metals and metalloids in eukaryotic and prokaryotic microbes. Comp Biochem Physiol A Mol Integr Physiol 133, 689-693.

Rutheford, J. C. \& Bird, A. J. (2004). Metal-responsive transcription factors that regulate iron, zinc and copper homeostasis in eukaryotic cells. Eukaryot Cell 3, 1-13.

Silver, S. (1996). Bacterial resistance to toxic metal ions - a review. Gene 179, 9-19.

Silver, S. \& Phung, L. T. (2005). A bacterial view of the periodic table: genes and proteins for toxic inorganic ions. I Ind Microbiol Biotechnol 32, 587-605.

Speir, T. V., Kettles, H. A., Parshotam, A., Searle, P. L. \& Vlaar, L. N. C. (1995). A simple kinetic approach to derive the ecological

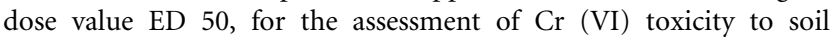
biological properties. Soil Biol Biochem 27, 801-811.

Tchounwou, P. B., Abdelghani, A. A., Pramar, Y. V., Heyer, L. R. \& Steward, C. M. (1996). Assessment of potential health risks associated with ingesting heavy metals in fish collected from a hazardous-waste contaminated wetland in Louisiana. Res Environ Health 11, 191-203.
Teitzel, G. M. \& Parsek, M. R. (2003). Heavy metal resistance of biofilm and planktonic Pseudomonas aeruginosa. Appl Environ Microbiol 69, 2313-2320.

Turpeinen, R., Kairesalo, T. \& Häggblom, M. M. (2004). Microbial community structure and activity in arsenic-, chromium- and copper-contaminated soils. FEMS Microbiol Ecol 47, 39-50.

Uriu-Adams, J. Y. \& Keen, C. L. (2005). Copper, oxidative stress, and human health. Mol Aspects Med 26, 268-298.

Valls, M. \& De Lorenzo, V. (2002). Exploiting the genetic and biochemical capacities of bacteria for the remediation of heavy metal pollution. FEMS Microbiol Rev 26, 327-338.

Vinuesa, P., Rademaker, J. L. W., De Bruijn, F. J. \& Werner, D. (1998). Genotypic characterization of Bradyrhizobium strains nodulating endemic woody legumes of the Canary Islands by PCR-restriction fragment length polymorphism analysis of genes encoding 16S rRNA (16S rDNA) and 16S-23S rDNA intergenic spacers, repetitive extragenic palindromic PCR genomic fingerprinting, and partial 16S rDNA sequencing. Appl Environ Microbiol 64, 2096-2104.

von Canstein, H., Li, Y., Timmis, K. N., Deckwer, W. D. \& WagnerDöbler, I. (1999). Removal of mercury from chloralkali electrolysis wastewater by a mercury-resistant Pseudomonas putida strain. Appl Environ Microbiol 65, 5279-5284.

Ward, B. B. \& O'Mullan, G. D. O. (2002). Worldwide distribution of Nitrosococcus oceani, a marine ammonia-oxidizing $\gamma$-proteobacterium, detected by PCR and sequencing of $16 \mathrm{~S}$ rRNA and amoA genes. Appl Environ Microbiol 68, 4153-4157.

Watanabe, K., Yamamoto, S., Hino, S. \& Harayama, S. (1998). Population dynamics of phenol degrading bacteria in activated sludge determined by gyrB-targeted quantitative PCR. Appl Environ Microbiol 64, 1203-1209.

Weisburgh, W. G., Barn, S. M., Pelletier, D. A. \& Lane, D. J. (1991). $16 \mathrm{~S}$ ribosomal DNA amplification for phylogenetic study. J Bacteriol 173, 697-703.

White, D. C., Sutton, S. \& Ringelberg, D. (1995). The genus Sphingomonas: physiology and ecology. Curr Opin Biotechnol 7, 301-306.

Yu, Z. \& Morrison, M. (2004). Comparison of different hypervariable regions of $r r s$ genes for use in fingerprinting of microbial communities by PCR-denaturing gradient gel electrophoresis. Appl Environ Microbiol 70, 4800-4806.

Edited by: C. Picioreanu 